Огляди літератури, оригінальні дослідження, погляд на проблему, ювілеї

УДК 616.37-002.2-02-036

DOI 10.11603/1811-2471.2018.v0.i3.9221

\title{
ЕТІОЛОГІЧНІ ФАКТОРИ, ЩО ФОРМУЮТЬ ХРОНІЧНИЙ ПАНКРЕАТИТ
}

\author{
ОТ. М. Христич, Д. О. Гонцарюк \\ ВГму України «Буковинський державний медичний університет», Чернівці
}

РЕЗЮМЕ. Хронічний панкреатит (ХП) - одне з поширених гастроентерологічних захворювань, яке становить близько 8-10 \% у структурі усіх захворювань органів травлення. Нерідко це захворювання діагностують пізно (алкогольної природи - до 30 місяців, іншої етіології - до 60 місяців від початку розвитку захворювання). За останні роки збільшилася частота захворювання на ХП, який супроводжується структурними змінами, що призводить до екзо- та ендокринної недостатності ПЗ, характеризується значним погіршенням якості життя і достатньо високим ризиком розвитку цукрового діабету й пухлин підшлункової залози. Через 10 років після встановлення діагнозу ХП приблизно 25 \% пацієнтів змушені залишити свою професійну діяльність або стають інвалідами. При цьому розвивається зовнішньосекреторна недостатність ПЗ, страждає травлення завдяки формуванню мальдигестії (синдром порушеного перетравлювання) та мальабсорбції (синдром зниженого всмоктування). Знання етіологічних чинників (куріння, алкоголізм, інфекційні, вірусні, гельмінтозні чинники, спадковість, метаболічний синдром, ендокринні захворювання, холелітіаз, хронічна ниркова недостатність тощо) при цьому мають значення не тільки для діагностики, але й для перебігу, диференційного діагнозу, лікування, реабілітаційних заходів та прогнозу перебігу захворювання.

КлючОВІ СлОВА: хронічний панкреатит; куріння; алкоголізм; холелітіаз; глистна інвазія; муковісцидоз; цукровий діабет; дисліпідемія; медикаментозний панкреатит.

Вступ. Часто ми зустрічаємося з гіпер- або гіподіагностикою хронічного панкреатиту, а іноді він має маски інших гастроентерологічних захворювань, у тому числі так званих «кислотозалежних». То що ж ми розуміємо під терміном «хронічний панкреатит»?

Хронічний панкреатит - це хронічне поліетіологічне запальне захворювання тканини підшлункової залози з вогнищевими, сегментарними або дифузними дегенеративними та деструктивними змінами паренхіми, з розвитком фіброзу та порушенням їі екзо- та ендокринної функцій.

У серпні 2016 на зустрічі Міжнародної асоціації панкреатологів, Японського панкреатологічного товариства, Азіатсько-Тихоокеанської асоціації панкреатологів у Синдаї американським професором D. Whitcomb було сформульоване нове визначення хронічного панкреатиту.

Хронічний панкреатит - че патологічний фіброзапальний синдром в осіб із генетичними зовнішніми та/або іншими факторами ризику, які призводять до розвитку персистуючої патологічної відповіді на ушкодження паренхіми або стрес [11].

Таке визначення базувалося на встановленні дисплазії, кальцифікації, фіброзу, атрофії паренхіми ПЗ на пізніх стадіях ХП, на наявності абдомінального болю, нерівності проток, їх стенозі, на порушенні зовнішньо- та внутрішньосекреторної функцій органа [12].

Важливим для клінічної практики, особливо для профілактичних заходів, $\epsilon$ знання етіології захворювань внутрішніх органів, у тому числі й панкреатиту. Тому метою даного огляду було висвітлити деякі етіологічні моменти, які призводять до розвитку та прогресування хронічного панкреатиту.

Одним з основних етіологічних факторів захворювання $\epsilon$ :

1. Куріння та вживання алкоголю (найчастіший фактор у чоловіків). Вважають, що куріння $\epsilon$ незалежним фактором виникнення гострого та хронічного панкреатиту. ХП у курців трапляється вдвічі частіше, ніж у некурців, а ризик розвитку захворювання зростає залежно від кількості викурюваних сигарет, що сприяє виснаженню запасів вітамінів С і А та знижує вміст інших антиоксидантів. Доведено, що ризик зростає від 1,0 для некурців до 4,5 разів для курців. Крім того, збільшується ризик кальцифікації ПЗ, порівняно з некурцями (частота розвитку складає 80 \% проти $40 \%$ ). При припиненні куріння тютюну знижується ризик розвитку ХП $[18,22]$.

Зловживання алкоголем - провідний етіологічний фактор ХП, який зустрічається в 65-85\% усіх випадків захворювання. Інтервал від початку систематичного зловживання до клінічних проявів панкреатиту становить 10 років [12]. Середня добова доза алкоголю досягає 100-200 мл, однак клінічні прояви ураження підшлункової залози виникають тільки в 5-10\% алкоголіків, ще у $10 \%$ випадків виявляють латентний хронічний панкреатит при автопсії. При цьому для гострих алкогольних панкреатитів характерні вакуолізація, некроз ацинарних клітин, набряк та інфільтрація паренхіми, крововиливи у тканину ПЗ. При хронічному перебігу типовими $\epsilon$ атрофія ацинарних клітин та фіброз. У патогенезі алкогольного панкреатиту значення мають токсичний вплив етано- 
Огляди літератури, оригінальні дослідження, погляд на проблему, ювілеї

лу, індивідуальна схильність. Ожиріння, куріння та ендотоксин грамнегативної кишкової флори (специфічний ліпополісахарид) також мають значення, оскільки в алкоголіків підвищена проникність слизової оболонки кишечника. Ліпополісахарид при цьому проникає в загальний кровообіг, ушкоджуються печінка, нирки, легені [3], розвиваються ускладнення з боку цих органів.

Зловживання алкоголем сприяє розвитку зовнішньосекреторної та трофологічної недостатності у таких хворих [2]. За даними 7 клінічних рандомізованих досліджень за участі пацієнтів із ХП частота абдомінального болю у тих, хто не вживав алкоголь, була значно нижчою, ніж у тих, хто продовжував зловживати [11, 20].

2. Камені у жовчному міхурі, холедосі найчастіше зустрічаються у жінок. Вплив холелітіазу на розвиток захворювання дуже значний, оскільки відбувається міграція конкрементів по жовчовивідних шляхах. Поєднання цих захворювань трапляється у 10,0 \% випадків. Також причиною розвитку хронічного біліарного панкреатиту можуть бути тривала гіпомоторна дискінезія жовчного міхура, спазм сфінктера Одді, анатомічні особливості жовчних та панкреатичних проток, місця їх з'єднань, їх довжина, діаметр, біліарний сладж, дуоденостаз і дуоденальна гіпертензія, а також хронічні захворювання печінки (стеатоз печінки, гепатити, цирози) [1, 9].

3. Недостатність альфа-1-антитрипсину, гіперхолестеринемія та вплив інших генетичних факторів. Вивченню значення генетичних факторів на сучасному етапі приділяється все більше уваги. Професор M. Lerch (Германія) на 45 конгресі Європейського клубу панкреатологів у 2013 році вказав, що мутація PRSS1 виявляється у 10 \% хворих проти 0 \% у загальній популяції; SPINK1 - у 15-25 \% проти 1-1,6 \%; CFTR - у 25-30 \% проти 10-15\%; CTRC-у 5 \% проти $1 \%$; CASR-у $19 \%$ проти $10 \%$. Встановлено, що середній час до появи перших симптомів панкреатиту, характерний для мутації $R 122 H$, складає 10 років, а втрата функціональної альтерації CTRC $\epsilon$ фактором, що сприяє розвитку панкреатиту, внаслідок трипсин-деградуючої активності [21]. Спадкова форма ХП характеризується тим, що клінічно проявляється у молодому віці. При цьому спостерігаються мутації PRSS1, який кодує катіонічний трипсиноген, а при муковісцидозі відмічена мутація гена CFTR та R334W-гена $[16,17]$.

4. Муковісцидоз - це спадкове захворювання 3 аутосомно-рецесивним типом успадкування, при якому ураження ПЗ відбувається внутрішньоутробно через мутацію гена муковісцидозу CFTR. Він $є$ регулятором трансмембранної провідності, що змінює кальцій-залежний регуляторний білок і порушує транспорт рідини у білковий субстрат панкреатичного соку. Завдяки цьому формується аномальний секрет - густий та в'язкий, що утруднює його рух по протоках і призводить до їх обструкції. Відбувається деструкція протокового й ацинарного епітелію із заміщенням фіброзною тканиною. Розвиваються фіброзний кістоз ПЗ, зовнішньосекреторна недостатність органа з моменту народження. Отже, муковісцидоз $\epsilon$ найчастішою спадковою патологією підшлункової залози, яка трапляється вже у дітей.

5. Роль харчування. У виникненні хронічного панкреатиту доведена негативна роль тяжкої білково-енергетичної недостатності з розвитком гіпоальбумінемії, дефіцитом вітамінів і мікроелементів (міді, селену). Тому недостатнє вживання 3 їжею білків, жирів та антиоксидантів й висококалорійна, багата на білок дієта з дуже високим або низьким вмістом жиру можуть погіршити функціональний стан ПЗ, якщо паралельно не застосовувати замісну ферментну терапію.

Вживання великої кількості овочів і фруктів захищає підшлункову залозу від захворювання. Вживання м'яса, холестерину, висококалорійних продуктів збільшує ризик виникнення пухлини. Але десятирічний перебіг ХП завдяки формуванню апоптотичних фіброзних змін (у тому числі і бета-клітин П3) сприяє розвиткові метаболічних порушень, які пов'язані з інсулінорезистентністю та дисліпідемією, що сприяє розвитку цукрового діабету.

Додатковим фактором ризику $\epsilon$ і постійне вживання фруктози, оскільки вона зменшує інсулінове інгібування печінкової глюкозної продукції, що є причиною печінкової інсулінової резистентності. Крім того, вона зменшує кількість АТФ (енергетичного субстрату для діяльності клітин) у гепатоцитах. Фруктоза може індукувати продукування сечової кислоти шляхом збільшення деградації АТФ до АМФ - попередника сечової кислоти (яка вже утворюється в надлишку завдяки гіперінсулінемії). Такі процеси поступово формують подагру. Це підтверджує проспективне дослідження на чоловіках, яке виявило, що цукро-підсолоджені газовані напої, фруктові соки та фруктоза асоціюються зі значно підвищеним ризиком гіперурикемії, подагри. Отже, споживання великої кількості фруктози вважають причиною інсулінорезистентності, гіпертригліцеридемії, метаболічного синдрому, цукрового діабету 2 типу, подагри, жовчних каменів, неалкогольного стеатогепатиту та хронічної хвороби нирок. Шляхами нівелювання негативних проявів можуть бути споживання фруктози не більше як 50 г/добу, урахування супутніх захворювань опорно-рухового апарату (у тому числі суглобів) та захворювань нирок. 
Огляди літератури, оригінальні дослідження, погляд на проблему, ювілеї

6. Захворювання ендокринних органів, зміни метаболізму. Етіологічна роль функціональних порушень щитоподібної та прищитоподібних залоз підтверджується тим, що видалення щитоподібної залози сприяє атрофії ПЗ, а призначення тиреоїдних гормонів, навпаки, сприяє відновленню маси органа. Дослідженнями останніх років встановлено, що рівень тиреотропного гормону контролює тиреотропний рилізинг гормон, який $\epsilon$ також в шлунково-кишковому тракті. У пацієнтів з гострим панкреатитом виявлено значне підвищення рівня цього гормону, що може свідчити про участь клітин ПЗ, які продукують такий гормон, у стресових реакціях на місцевому рівні, що й сприяє підвищенню його рівня в крові та сечі. Крім того, встановлена властивість цього ферменту пригнічувати секрецію і виділення панкреатичних ферментів [35]. Імовірно, при загостренні хронічного панкреатиту підвищення концентрації тиреотропного гормону може мати компенсаторний характер, спрямований на пригнічення зовнішньосекреторної функції ПЗ.

Суттєву роль у регуляції кальцієвого обміну мають гормон щитоподібної залози кальцитонін та гормон прищитоподібної залози паратгормон. Встановлено, що у пацієнтів із значним зниженням зовнішньосекреторної функції ПЗ концентрація кальцитоніну низька, а рівень паратгормону підвищується. У хворих із тяжким перебігом хронічного панкреатиту рівні гормонів стають високими. Часто підвищення кальцитоніну корелює з підвищенням рівня глюкагону в крові, що можна трактувати як адаптаційну реакцію. При довготривалому перебігу хронічного панкреатиту розвивається гіпокальціємія, що проявляється болем у кістках при ходьбі, фізичних навантаженнях [35].

Гіперкальціємія частіше виникає при гіперпаратиреозі. Знайдено певний зв'язок між вираженістю гіперпаратгормонемії та ступенем морфологічних змін у ПЗ (кальцифікація ПЗ, активація зовнішньосекреторної функції, а саме, трипсиногену, призводить до вогнищ аутолізу П3) [6]. Крім того, кальцій стимулює зовнішньосекреторну функцію ПЗ, внутрішньоорганно активує трипсиноген, що призводить до виникнення вогнищ аутолізу.

При гіперкортицизмі також відбувається надлишкова стимуляція панкреатичної секреції, знижується використання глюкози тканинами. Крім того, адреналін та норадреналін пригнічують секрецію інсуліну. Значення у цьому процесі має й АКТГ, він прямо впливає на надниркові залози. Але відомі й такі дії кортикотропіну в жировій тканині, як посилення процесів ліполізу, стимуляція поглинання м'язовими тканинами амінокислот і глюкози, що викликає гіпоглікемію, стимулюючи звільнення інсуліну з бета-клітин ПЗ.
Естрогени викликають резистентність до інсуліну, а соматотропний гормон підвищує глюкогенез та знижує засвоєння глюкози тканинами. Такі процеси сприяють порушенню вуглеводного обміну, формуванню хронічного панкреатиту й інсулінорезистентності з наступним розвитком метаболічних захворювань.

Гіперліпідемія і гіпертригліцеридемія часто виникають при збільшенні вмісту тригліцеридів понад 1000 мг/дл. Щодо впливу гіперліпідемії на розвиток захворювання, наводяться дані, які свідчать про можливе виникнення жирової дистрофії підшлункової залози, стеатопанкреатиту (особливо при ЦД типу 2) [14]. У цьому процесі бере участь і соматотропний гормон. При хронічному підвищенні соматотропного гормону підсилюється використання глюкози жировими тканинами і м'язами, посилюється глюкогенез у печінці. Компенсація діабетогенного впливу соматотропного гормону відбувається завдяки підвищенню секреції інсуліну, що супроводжується гіперінсулінемією (в тому числі й завдяки зменшенню інсулінових рецепторів), яка при виснаженні резервних можливостей бета-клітин ПЗ може змінюватися гіпоінсулінемією, абсолютною недостатністю інсуліну та розвитком цукрового діабету.

Цукровий діабет типу 2 із ожирінням сприяє проліферації панкреатичних проток, їх блокуванню, деструкції і схильності до формування метаплазії, дисплазії та раку ПЗ. При метаболічному синдромі розвиваються жовчнокам'яна хвороба, неалкогольна жирова хвороба печінки, неалкогольна жирова хвороба ПЗ. Але японські вчені на достатньому клінічному матеріалі показали, що неалкогольна жирова хвороба печінки може розвинутись і після резекції ПЗ або панкреатектомії. Такий розвиток асоціюється із атрофією кукси залози, розширенням вірсунгової протоки, трофологічною недостатністю та атрофією m.liopsoas. Однією 3 причин вважають мальнутрицію, яка супроводжує зовнішньосекреторну недостатність ПЗ.

7. Негативний вплив медикаментів (аспірин, тетрациклін, фуросемід, імунодепресанти, антикоагулянти, хлортіазид, глюкокортикостероїди, нестероїдні протизапальні препарати (НПЗП), сульфаніламіди, парацетамол, застосування пероральних контрацептивів).

Частота медикаментозного панкреатиту складає 2-5 \% всіх гострих панкреатитів. Медикаментозний панкреатит не буває хронічним. Тяжкість перебігу варіює від легкого до вкрай тяжкого, з високим ризиком летальності (особливо за геморагічної некротичної форми). Це має місце при дисемінованому туберкульозі або СНІДі. у багатьох випадках медикаментозний панкреатит має добрий прогноз. Розрізняють три рівні гострого 
Огляди літератури, оригінальні дослідження, погляд на проблему, ювілеї

пошкодження ПЗ. Певний гострий панкреатит (якщо КТ, УЗД, лапаротомія або аутопсія підтверджують його наявність). Про можливий гострий панкреатит може йтися, якщо є типові симптоми та триразове підвищення рівня амілази, ліпази в крові. Діагноз ймовірного гострого панкреатиту встановлюють завдяки наявності абдомінального больового синдрому при відсутності підвищення рівня амілази крові або при безсимптомному підвищенні ферментів ПЗ.

8. Вплив вірусів, бактерій та паразитів. ХП викликають віруси гепатитів В і С у реплікативній фазі, ентеровіруси, цитомегаловіриси, віруси Коксакі, ЕСНО, Епштейна-Барр, герпесу, епідемічного паротиту та бактерії (сальмонели, камбілобактерії, хламідії, мікоплазми, туберкульозна паличка) [13]. Інфекції та паразити (аскаридоз, опісторхоз) також мають відповідну нішу в етіології ХП.

Недооцінюється значення аскаридозу і кишкових гельмінтів як першопричина виникнення ХП. Їх небезпека пов'язана із здатністю індукувати загрозливі для життя ускладнення (закупорка проток панкреатобіліарної системи, абсцеси печінки та ПЗ, обтураційна кишкова непрохідність). Обструкція може відбуватися завдяки дорослим аскаридам, звапнілим загиблим аскаридам, обтурації яйцями гельмінтів. Тяжкість перебігу ХП залежить від локалізації та інтенсивності інвазії. Якщо інвазія $\epsilon$ тільки в панкреатичній протоці, то гострий панкреатит проходить легко. Якщо ж вона $є$ в панкреатичній і жовчній протоках з блокадою фатерового сосочка, то розвивається тяжкий, часто ускладнений перебіг з можливим летальним наслідком через розвиток ускладнень гнійного характеру (13\%). Часто зустрічається надрив слизової оболонки панкреатичних та жовчовивідних шляхів з розвитком кровотеч. При повторному зараженні патологоанатомічні зміни менш виражені, можливо, за рахунок імунітету, який зберігається впродовж кількох місяців і до реінвазії. Отже, слід враховувати, що аскаридоз (наявний або перенесений) впливає на перебіг ХП, поглиблює трофологічні порушення (анемію, гіповітамінози, імунодефіцити), що погіршує якість життя [15].

Onicmoрхоз є ендемічним захворюванням (в Україні зустрічається в басейні Дніпра). Причиною розвитку є вживання з їжею риби, яка заражена котячою двоусткою. Вона паразитує у протоках ПЗ та жовчних шляхах. При цьому порушується відтік панкреатичного соку, жовчі, виникає вторинна бактеріальна інфекція, з'являються токсичні та алергічні ознаки. Розвивається сенсибілізація організму продуктами паразита, виникають механічні ушкодження тканини печінки, ПЗ, впливаючи на нервову систему. Перебіг захворювання тривалий, з інтенсивним абдомінальним болем в епігастральній зоні, правому підребер'ї, артралгіями, вираженими диспепсичними скаргами, інтенсивним головним болем. Такий початок характерний для гострої стадії захворювання. Для неї характерні наступні синдроми: гепатобіліарний, холангіопанкреатичний, шкірний, холецистоподібний, суглобовий з міопатією, лімфаденопатичний, бронхолегеневий, кардіальний, нирковий, астеновегетативний. При пізній стадії захворювання (хронічній) хворі скаржаться на абдомінальний біль меншої інтенсивності в епігастральній ділянці, правому підребер'ї з ірадіацією у спину, ліве підребер'я. Виникають головний біль, диспепсичний синдром, типовий панкреатичний больовий синдром з іррадіацією у ділянку селезінки. Поступово розвивається зовнішньо- та внутрішньосекреторна недостатність ПЗ.

Лямбліоз. Зараження відбувається фекальнооральним механізмом передачі інфекції при вживанні забруднених цистами продуктів харчування (особливо фруктів, овочів, ягід, що не піддалися термічній обробці) і води, а також через забруднені цистами руки і предмети побуту. Лямблії існують у двох формах: рухомій (вегетативній) і нерухомій (форма цисти). Потрапивши в травну систему здорової людини, лямблії розмножуються в тонкій кишці, іноді у великих кількостях, і спричинюють порушення травлення, які проявляються, в першу чергу, дуоденітом. З'являються біль у верхній частині живота або в ділянці пупка, здуття живота, бурчання, нудота. Можуть бути запори, що змінюються проносами. Можливі дискінезії жовчних шляхів. Симптоми можуть бути слабо вираженими або ураження може перебігати безсимптомно. Хвороба перебігає тяжче при супутній ахілії та недостатності функції підшлункової залози.

Вірусні панкреатити. Інфекційним панкреатитом називають захворювання, причиною якого став вірус, що негативно впливає на секреторну функцію П3, або якщо вогнища виникли у процесі розвитку вірусного захворювання та погіршили загальний стан пацієнта. Значну роль у формуванні панкреатиту мають вірусний гепатит С, вірус Коксакі, вірус кору, паротиту, цитомегаловірус тощо. У дітей з хронічними хворобами вогнища інфекції у підшлунковій залозі зустрічаються частіше, ніж при гострих. Вірусний патогенез достатньо не вивчений. Вважають, що значення має аутоперетравлювання тканини залози ферментами, а прискорення апоптозу та дистрофія ациноцитів викликає фіброз. Частіше інфекційний панкреатит викликають вірусні гепатити, оскільки цьому сприяють загальні протоки, іннервація, лімфатичні шляхи, кровопостачання. Значення має і дуоденопанкреатичний рефлюкс. Загальними симпто- 
Огляди літератури, оригінальні дослідження, погляд на проблему, ювілеї

мами вважають лихоманку, лейкоцитоз, можливе утворення кіст.

9. Хронічна ниркова недостатність (ХНH) збільшує вірогідність розвитку ХП завдяки тому, що рівень креатиніну в крові перевищує 300 мкг/мл. При цьому підвищується концентрація гастрину, холецистокініну, гастроінгібувального поліпептиду та глюкагону, яка не знижується навіть при гемодіалізі (за винятком гастроінгібувального поліпептиду). Тобто підвищується концентрація гормонів, які стимулюють ферменти ПЗ, особливо протеолітичні (гіперхолецистокінінемія стимулює секрецію трипсину, а не ліпази) [5]. Відомо, що при хронічній нирковій недостатності встановлені гістологічні зміни у 57 \% випадків. Зміни характеризувалися розширенням проток із фіброзом тканин навколо них, проліферацією клітин проток та ацинарною матаплазією. Ці зміни були схожими до таких, що характеризують стан після внутрішньопротокової преципітації білка завдяки надлишку алкоголю.

10. Існують і доброякісні панкреатичні гіперферментемії. Все частіше трапляються випадки безсимптомного підвищення активності амілази, панкреатичної ізоамілази, ліпази та трипсину. У таких клінічних випадках припускають, що це $\epsilon$ маркером субклінічного перебігу ХП. Підвищення рівня ферментів ПЗ найчастіше асоціюється не тільки з панкреатитом, а й із захворюваннями жовчовивідних шляхів, печінки, дванадцятипалої

\section{ЛІТЕРАТУРА}

1. Бабінець Л. С. Актуальні аспекти формування хронічного біліарного панкреатиту / Л. С. Бабінець, К. Ю. Кицай // Вестник клуба панкреатологов. - 2015. № 4 (32). - С. 46-50.

2. Бабінець Л. С. Кореляція між трофологічним статусом та основними характеристиками захворювання у пацієнтів із хронічним панкреатитом біліарного ґенезу / Л. С. Бабінець, Ю. Я. Коцаба, К. Ю. Кицай, І. М. Галабіцька // Вестник клуба панкреатологов. - 2017. - № 1 (34). - С. 38-40.

3. Гонцарюк Д. О. Роль мікробіоти у перебігу та розвитку метаболічних процесів при хронічному панкреатиті / Д. О. Гонцарюк, Т. Н. Христрч // Вестник Клуба панкреатологов. - 2017. - № 4 (37). - С. 22-26.

4. Губергриц Н. Б. Клиническая панкреатология / Н. Б. Губергриц, Т. Н. Христич. - Донецк : ООО «Лебедь», 2000. -416 c.

5. Губергриц Н. Б. Метаболическая панкреатология / Н. Б. Губергриц, А. Н. Казюлин. - Донецк : ООО «Лебедь», 2011. - 460 с.

6. Губергриц Н. Б. Гиперпаратиреоз: панкреатит и другие остроэнтерологические проявления / Н. Б. Губергриц // Вестник клуба панкреатологов. - 2015. - № 2 (27). - C. 4-7. кишки, хворобою Уіпла, нирковою недостатністю, ураженнями слинних залоз, раком легень, ВІЛ/СНІД, феохромоцитомою, позаматковою вагітністю тощо. Причиною підвищення амілази може бути не тільки діяльність ацинарних клітин, але й інших органів і тканин. Так, ліпаза синтезується ще й у шлунку, кишечнику, головному мозку, іï знаходять в слині. Трипсин вважють панкреатоспецифічним ферментом, проте його показники змінюються також при захворюваннях органів гепатобіліарної зони, при хронічній нирковій недостатності (це пов'язано з порушенням виведення ферменту та його накопиченням).

Крім того, існує персистуюча безсимптомна гіперферментемія, яку в 1996 році італійський дослідник Гулло назвав «доброякісною панкреатичною гіперферментемією». Згодом синдром Гулло було виділено як сімейну панкреатичну гіперферментемію. Він може поєднуватися з синдромом Жильбера, безсимптомним підвищенням креатинфосфокінази, трансаміназ [8].

Висновок. Етіології хронічного панкреатиту необхідно приділяти увагу, оскільки це захворювання $€$ поліетіологічним і поліпатогенетичним, тому завдяки лікуванню (або профілактиці) базисної хвороби можна отримати ліпший та швидший ефект. Реабілітаційні програми також необхідно будувати з урахуванням етіологічних впливів на перебіг хронічного панкреатиту та його розвиток.

7. Губергриц Н. Б. Панкреатический асцит: еще одно из многих проявлений панкреатита / Н. Б. Губергриц, Н. В. Беляева, П. Г. Фоменко // Вестник клуба панкреатологов. - 2016. - № 2 (31). - С. 13-16.

8. Клиническое наблюдение семейной доброкачественной панкреатической гиперферментемии / Е. Ю. Губская, Н. Б. Губергриц, А. Е. Клочков [и др.] // Вестник клуба панкреатологов. - 2017. - № 4 (37). - С. 47-52.

9. Расстройства желчного пузыря и сфинктера Одди в Римских критериях IV: диагностические возможности или в поисках «золотого стандарта» / Л. В. Журавлёва, Т. А. Моисеенко, М.В. Филоненко, А. К. Журавлёва //Вестник клуба панкреатологов. - 2017. - № 4 (32). - С. 53-63.

10. Казюлин А. Н. Современные представления о6 этиологии хронического панкреатита / А. Н. Казюлин // Вестник клуба панкреатологов. - 2016. - № 3 (32). - С. 40.

11. Новости Европейской панкреатологии (по материалам 48-й встречи Европейского Клуба панкреатологов, 6-9 июля 2016 г., Ливерпуль, Великобритания) / Н. Б. Губергриц, Н. В. Беляева, Г. М. Лукашевич [и др.] // Вестник Клуба панкреатологов. - 2016. - № 4 (33). - C. 11-20.

12. Развитие фиброза в ткани поджелудочной железы и содержание TNF-альфа в сыворотке крови 
Огляди літератури, оригінальні дослідження, погляд на проблему, ювілеї

больных алкогольным панкреатитом / О. И. Березина, Л. В. Винокурова, В.Н.Дроздов [и др.] // Патология органов пищеварения и ассоциированные с ней заболевания. Пробемные вопросы и пути их решения : XI Научное общество гастроэнтерологов России, 1-2 марта, 2011 г. : тезисы докл. - Москва, 2011. - С. 143.

13. Христич Т.Н.Хронический панкреатит: нерешенные проблемы / Т. Н. Христич, В. П. Пишак, Т. Б. Кендзерская. - Черновцы, 2006. - 280 с.

14. Христич Т. М. Роль підшлункової залози в регуляції системного метаболізму та адаптивних функцій / Т. М. Христич, Т. Б. Кендзерська, О. І. Чернявський // Новости медицины и фармации. Гастроэнтерология. 2007. - № 226. - C. 7-8.

15. Христич Т. Н. Паразитарный генез хронических панкреатитов / Т. Н. Христич, Т. Б. Кендзерская, Л. Д. Кушнир // Гастроентерологія. Міжвідомчий збірник. - 2007. - Вип. 39. - С. 140-145.

16. Наследственный панкреатит / Т. Н. Христич, Т. Б. Кендзерская, В. П. Пишак, Н. Б. Губергриц // Новости медицины и фармации. Гастроэнтерология. - 2009. № 301. - С. 87-93.

17. Циммерман Я. С. Современные возможности фармакотерапии хронического панкреатита / Я. С. Цим- мерман // Вестник клуба панкреатологов. - 2017. - № 2 (35). - C. 26-31.

18. Чрезмерное курение связано с развитием первого эпизода острого панкреатита в более молодом возрасте и с высоким риском рецидива острого панкреатита / S. Munigala, D. L. Conwel, A. Gelrud, B. Agarwal // Вестник клуба панкреатологов. - 2015. - № 3 (31). C. 27-34.

19. Эпидемиология хронического панкреатита / P. Levy, E. D. Domingues-Munoz, C. Imre, M. Lohr, P. Masionneuve // Вестник клуба панкреатологов. 2015. - № 3 (28). - C.7-16.

20. Ярошенко В. Г. Выбор метода хирургического лечения хронического панкреатита и его осложнений / В. Г. Ярошенко, Ю. А. Михеев // XXIII з'їзд хірургів України. 3бірник наукових робіт. - Київ, 2015. - С. 219-220.

21. Rosendahi J. Chymotrypsin C (CTRC) variants that diminish activity or secretion are associated with chronic pancreatitis / J. Rosendahi, H. Witt, R. Szmola // Nat. Genet. - 2008. - Vol. 40, No. 1. - P. 78-82.

22. Small gallstones preserved gall bleder motilite and fast crystallization are associated wsth pancreatitis / N. G. Venneman, W. Renooij, J. F. Rehfeld [et al.] // Hepatology. - 2005. - Vol. 41. - P. 738-746.

\section{REFERENCES}

1. Babinets, L.S. (2015). Aktualni aspekty formuvannia khronichnoho biliarnoho pankreatytu [Actual aspects of formation of chronic biliary pancreatitis]. Vestnik kluba pankreatologov - Bulletin of the Club of Pancreatologists, 4 (32), 46-50 [in Ukrainian].

2. Babinets, L.S. (2017). Koreliatsiia mizh trofolohichnym statusom ta osnovnymy kharakterystykamy zakhvoriuvannia u patsiientiv iz khronichnym pankreatytom biliarnoho genezu [Correlation between the trophological status and the main characteristics of the disease in patients with chronic bronchial pancreatitis]. Vestnik kluba pankreatologov-Bulletin of the Club of Pancreatologists, 1 (34), 38-40 [in Ukrainian].

3. Hontsariuk, D.O., \& Khrystych, T.N. (2017). Rol mikrobioty u perebihu ta rozvytku metabolichnykh protsesiv pry khronichnomu pankreatyti [The role of microbiota in the course and development of metabolic processes in chronic pancreatitis]. Vestnik kluba pankreatologov-Bulletin of the Club of Pancreatologists, 4 (37), 22-26 [in Ukrainian].

4. Gubergrits, N.B. (2000). Klinicheskaya pankreatologiya [Clinical pancreatology]. Donetsk: OOO "Lebed” [in Russian].

5. Gubergrits, N.B., \& Kazyulin, A.N. (2011). Metabolicheskaya pankreatologiya [Metabolic pancreatology]. Donetsk: OOO "Lebed" [in Russian].

6. Gubergrits, N.B. (2015). Giperparatireoz: pankreatit i druhiye gostroenterologicheskiye proyavleniya [Нyperрarathyroidism: pancreatitis and other gastro enterological manifestations]. Vestnik kluba pankreatologov-Bulletin of the Club of Pancreatologists, 2 (27), 4-7 [in Russian].

7. Gubergrits, N.B. (2016). Pankreaticheskiy astsit: eshche odno iz mnogikh proyavleniy pankreatita [Pancreatic ascites: another of many manifestations of pancreatitis]. Vestnik kluba pankreatologov-Bulletin of the Club of Pancreatologists, 2 (31), 13-16 [in Russian].

8. Hubskaya, E. Yu. (2017). Klinicheskoe nablyudeniye semeynoi dobrokachestvennoi pankreatycheskoi hyperfermentemyy [Clinical observation of familial benign pancreatic hyperfermentemia]. Vestnik kluba pankreatologov - Bulletin of the Club of Pancreatologists, 4 (37), 4752 [in Russian].

9. Zhuravliyova L.V. (2009). Rasstroystva zhelchnogo puzyrya i sfinktera Oddy v Rimskikh kriteriyakh IU: diagnosticheskye vozmozhnosti ili v poiskakh "zolotogo standarta" [Disorders of the gall bladder and sphincter of Oddi in the Roman criteria IU: diagnostic possibilities or in search of "gold standard"]. Vestnik kluba pankreatologovBulletin of the Club of Pancreatologists, 4 (32), 53-63 [in Russian].

10. Kazyulin, A.N. (2016). Sovremennye predstavleniya ob etiologii khronicheskogo pankreatita [Modern ideas about the etiology of chronic pancreatitis]. Vestnik kluba pankreatologov - Bulletin of the Club of Pancreatologists, 3 (32), 40 [in Russian].

11. Gubergrits, N.B., Belyayeva, N.V., Lukashevich, G.M., Klochkov, A.E., \& Fomenko, P.G. (2016). Novosti Yevropeyskoy pankreatologii (po materialam 48-y vstrechi Yevropeyskogo Kluba pankreatologov) [News of European pancreatology (based on the materials of the 48th meeting of the European Pancreatology Club, July 6-9, 2016, Liverpool, United Kingdom)]. Vestnik Kluba pankreatologov- Bulletin of the Club of Pancreatologists, 4 (33), 11-20 [in Russian].

12. Berezina, O.I., Vinokurova, L.V., \& Drozdov, V.N. (2011). Razvitye fibroza $v$ tkani podzheludochnoy zhelezy i soderzhaniye TNF-alfa v syvorotke krovi bolnykh alkogolnym pankreatitom [The development of fibrosis in pancreatic tissue and the content of TNF-alpha in the serum of patients with alcoholic pancreatitis]. Patologiya organov pishchevareniya $i$ assotsiirovannyye $s$ ney zabolevaniya. 
Огляди літератури, оригінальні дослідження, погляд на проблему, ювілеї

Probemnye voprosy i puti ikh resheniya: Khl Nauchnoe obshchestvo gastroenterologov Rossii - Pathology of the digestive system and associated diseases. Probing questions and ways of their solution: XI Scientific Society of Gastroenterologists of Russia. Moscow [in Russian].

13. Khristich, T.N. (2006). Khronicheskiy pankreatit: nereshennyye problem [Chronic pancreatitis: unsolved problems]. Chernivtsi [in Russian].

14. Khrystych, T.M. (2007). Rol pidshlunkovoi zalozy $v$ rehuliatsii systemnoho metabolizmu ta adaptyvnykh funktsii [The role of pancreas in the regulation of systemic metabolism and adaptive functions]. Novosti meditsyny i farmatsii. Hastroenterolohiia - News of Medicine and Pharmacy.- Gastroenterology, 226,7-8 [in Ukrainian].

15. Khristich, T.N. (2007). Parazitarnyy genez khronicheskikh pankreatitov. Gastroenterologiya [Parasitic genesis of chronic pancreatitis. Gastroenterology]. Mizhvidomchyi zbirnyk - Interdepartmental Compilation, 39, 140-145 [in Ukrainian].

16. Khristich, T.N. (2009). Nasledstvennyy pankreatit [Hereditary pancreatitis]. Novosti meditsyny i farmatsii. Gastroenterologiya - News of Medicine and Pharmacy. Gastroenterology, 301, 87-93 [in Russian].

17. Tsimmerman, Ya.S. (2017). Sovremennyye vozmozhnosti farmakoterapii khronycheskogo pankreatita [Modern possibilities of pharmacotherapy of chronic pancreatitis]. Vestnik kluba pankreatologov - Bulletin of the
Club of Pancreatologists, 2 (35), 26-31 [in Russian].

18. Munigala, S., Conwel, D., Gelrud, A., \& Agarwal, B. (2015). Chrezmernoye kurenye svyazano s razvityem pervogo epizoda ostrogo pankreatita v boleye molodom vozraste i s vysokim riskom retsidiva strogo pankreatita [Excessive smoking is associated with the development of the first episode of acute pancreatitis at a younger age and with a high risk of recurrence of severe pancreatitis]. Vestnik kluba pankreatologov - Bulletin of the Club of Pancreatologists, 3 (31), 27-34 [in Russian].

19. Levy, P., Domingues-Munoz, E.D., Imre, C., Lohr, M., \& Masionneuve, P. (2015). Epydemiologiya khronicheskogo pankreatita [Epidemiology of chronic pancreatitis]. Vestnik kluba pankreatologov - Bulletin of the Club of Pancreatologists, 3 (28), 7-16 [in Russian].

20. Yaroshenko, V.H. (2015). Vybor metoda khirurgicheskogo lecheniya khronicheskogo pankreatita i yeho oslozhneniy [Choice of the method of surgical treatment of chronic pancreatitis and its complications]. XXIII zizd khirurhiv Ukrainy. Zbirnyk naukovykh robit - XXIII Congress of Surgeons of Ukraine. Collection of Scientific Works. Kyiv, 219-220 [in Russian].

21. Rosendahi, J., \& Chymotrypsin, C. (2008). (CTRC) variants that diminish activity or secretion are associated with chronic pancreatitis. Nat. Genet., 40 (1), 78-82.

22. Venneman, N.G., Renooij, W., \& Rehfeld, J.F. (2005). Small gallstones preserved gall bledermotilite and fast crystallization are associated with pancreatitis

Hepatology, 41, 738-746.

\title{
ЭТИОЛОГИЧЕСКИЕ ФАКТОРЫ, ФОРМИРУЮЩИЕ ХРОНИЧЕСКИЙ ПАНКРЕАТИТ
} ОТ. Н. Христич, Д. А. Гонцарюк

\author{
ВГМУ Украины «Буковинський государственный медицинский университет», Черновцы
}

РЕЗЮМЕ. Хронический панкреатит (ХП) - это одно из распространенных гастроэнтерологических заболеваний, составляющее около 8-10 \% в структуре всех гастроэнтерологических заболеваний органов пищеварения. Нередко данное заболевание диагностируется поздно (алкогольной природы - до 30 месяцев, другой этиологии - до 60 месяцев от начала развития болезни). В последние годы увеличилась частота заболеваемости ХП, что сопровождается структурными изменениями, приводящими к экзо- и эндокринной недостаточности Пж, характеризуется ухудшением качества жизни и достаточно высоким риском развития сахарного диабета и опухолей поджелудочной железы. Через 10 лет после установления диагноза ХП приблизительно 25 \% пациентов вынуждены оставить свою профессиональную деятельность и становятся инвалидами. При этом развивается внешнесекреторная недостаточность ПЖ, страдает пищеварение вследствие формирования мальдигестии (синдром нарушенного всасывания) и мальабсорбции (синдром нарушенного всасывания). Знание этиологических факторов (табакокурение, алкоголизм, инфекционные, вирусные факторы, гельминтозные инвазии, холелитиаз, хроническая почечная недостаточность и т.д.) при этом имеют значение не только для диагностики, но и для клинического течения, дифференциального диагноза, лечения, реабилитационных мероприятий и прогноза течения заболевания.

КЛЮчЕВЫЕ СЛОВА: хронический панкреатит; табакокурение, алкоголизм, холелитиаз, глистная инвазия, сахарный диабет, дислипидемия, медикаментозний панкреатит.

\section{ETIOLOGICAL FACTORS WHICH FORM THE CHRONICAL PANCREATITIS}

\author{
@T. M. Hristich, D. O. Hontsariuk \\ Bukovyna State Medical University, Chernivtsi
}

SUMMARY. Chronic pancreatitis (CP) is one of the most common gastrointestinal diseases, accounting for about 8-10\% in the structure of all gastroenterological diseases of the digestive system. Often this disease is diagnosed late 
Огляди літератури, оригінальні дослідження, погляд на проблему, ювілеї

(alcohol icnature - up to 30 months, an other etiology - up to 60 months from the beginning of the disease). In recent years, the incidence of CP has increased, which is accompanied by structural changes leading to exo-and endocrine pancreatic insufficiency, characterized by a deterioration in the quality of life and a relatively high risk of developing diabetes and pancreatic tumors. Ten years after the diagnosis of CP, approximately $25 \%$ of patients are forced to leave their professional activities and become disabled. This develops the external secretory deficiency of the prostate, suffers from digestion due to the formation of maldigestion (syndrome of impaired absorption) and malabsorption (syndrome of impaired absorption). Knowledge of etiologic factors (tobacco smoking, alcoholism, infectious, viral factors, helminthic nausea, cholelithiasis, chronic renal failure, etc.) are important not only for diagnosis, but also for clinical course, differential diagnosis, treatment, rehabilitation activities and prognosis of the course of the disease.

KEY WORDS: chronic pancreatitis; smoking; alcoholism; cholelithiasis; helminthic invasion; diabetes mellitus; dyslipidemia; medical pancreatitis.

Отримано 27.08.2018 